\title{
LITERATURE RESEARCH IN THE FIELD sciendo OF TECHNOLOGY ASSESSMENT USING A TOOL OF A SYSTEMATIC LITERATURE REVIEW
}

doi:10.2478/mape-2018-0015

Date of submission of the article to the Editor: 04/2018

Date of acceptance of the article by the Editor: 07/2018

MAPE 2018, volume 1, issue 1, pp. 109-115

PhD. Student, MSc. Eng. Dorota Palka

Dr hab. inż. Jarosław Brodny

Silesian University of Technology, Poland

Assoc. Prof. Tamer Rızaoğlu

Kahramanmaraş Sütçü Imam University, Turkey

Assoc. Prof. Dr Utku Bağci

Mersin University, Turkey

Ing. Jozef Maščeník, PhD.

Technical University Kosice, Slovak Republic

\begin{abstract}
The article presents the results of literature research in the field of Technology Assessment (TA). In particular, the attention was focused on searching for trends determining the directions of development of this research area. Research gaps constituting the basis for undertaking new cognitive challenges were identified. As a research method, a systematic review of literature was adopted, the methodology of which was described in the first part of the article. The analysis includes a total of 1788 TA-related scientific articles available in Google Scholar and BazTech databases. The practical part of the article presents fragments of literature research and an attempt to define the concepts of Technology Assessment on their basis. The collected research material showed a high degree of variation in the scope of definitions and the research area covered by TA. This indicates the need to conduct further research in this area for the purpose of clarifying the research area which TA deals with. It is legitimate to say that the development of research in this area is necessary due to the increasing impact of technology on society.
\end{abstract}

Keywords: increasing technology, scientific literature, systematic literature review, Technology Assessment

\section{INTRODUCTION}

Globalization, technological progress and increasing competition on global markets determine the growing use of new technologies. Innovative solutions determine the competitive advantage of enterprises, and thus form the basis for the introduction of modern production systems.

The dynamic development of technology is visible in almost every area of life. This also applies to industries that are considered to be very conservative in the area of introducing new solutions. A good example can be mining, where new technical solutions are being introduced to a wider extent, also in the field of broadly understood IT and telecommunications (Brodny et al., 2017; Stecuła et al., 2017b; Stecuła et al., 2018). In this particular industry, this also applies to new methods of combating various types of natural hazards (Tutak, 2017a; Tutak, 2017b; Tutak and Brodny, 2017a; Tutak and Brodny, 2017b), and machine operation (Brodny et al., 2017; Stecuła et al., 2017a; Stecuła et al., 2018). The fast pace of introducing new technologies is becoming a bigger and bigger barrier also for other industries as well as for many social groups. In many cases this leads to social or professional exclusion. A large group 
of society (users) does not understand how new devices work and how to use them. The lack of technical knowledge means that the changes introduced are often negatively perceived by employees (Palka, 2017). According to K. Halicka, in the situation of the growing demand for innovative technologies and the broad market of technologies turnover, the issue of in-depth analysis of technology is of great importance. However, this in-depth technology analysis is difficult to conduct due to its costs, complexity and, above all, the pace of technological changes on the global market. (Halicka, 2014). Such analysis should take into account economic, technical, ecological and social factors. It is therefore necessary to use appropriate methods and tools to valuate technology. For this purpose, it is necessary to get acquainted with all the issues related to this problem and called Technology Assessment (TA).

TA is considered an interdisciplinary approach to solving existing problems and preventing potential damage caused by uncritical use and commercialization of new technologies (Krawot, 2018). In order to valuate technology, it is crucial to create a methodological background, to develop methodology and methods, and to analyze the achievements of various scientific disciplines. This means the need to conduct extensive research and to integrate diverse scientific environments.

Scientific work requires constant knowledge development, formulation of new research problems, and thus the knowledge of the existing state of science and the recognition of previously performed research in the implemented area. The creation of diploma theses, research projects or writing scientific articles requires a prior analysis of the current state of knowledge in the discussed research area. Scientific research conducted in a new subject should refer to the previous ones in order to broaden the existing state of knowledge, to verify it or to change it. In order for such research to fulfill its function, it is necessary to conduct an in-depth literature analysis on a given topic. The aim of this analysis is to acquire knowledge about the current state of scientists' research in a given topic, which should enable the formulation of research questions and the interpretation of the results of empirical research (Czakon, 2011).

In the times of rapid development of information technology, the access to literature sources (information, knowledge) is practically unlimited. The variety of scientific databases or literature browsers creates enormous opportunities to search for the entries and topics we are interested in from various sources. Modern system functions enable automatic searching of databases, creating alerts about the latest publications, etc. However, in order to obtain reliable and transparent data, it is necessary to introduce methodical rigor. Therefore, in order to determine the research area and to define TA, literature research was conducted using the Systematic Literature Review (SLR) method which is one of the most transparent and frequently used techniques in this field.

\section{CHARACTERISTICS OF SYSTEMATIC LITERATURE REVIEW}

Literature review is usually seen as the beginning of proper research activities. Practice shows, however, that this review has a huge impact on the entire research process. In many cases it is the basis for the adopted assumptions, hypotheses and defined research problems. For this reason, literature review must be adequately prepared and carried out in a methodical manner. The Systematic Review of Literature methodology serves this purpose. There are several definitions of Systematic Literature Review in the literature. In Polish publications, the SLR has been defined as follows:

"A systematic review of the literature is a method of integrating scientific evidence, in which explicit methods of identification, selection, critical evaluation and analysis of data from relevant studies qualified for the review are used. This method complements the limitations of traditional reviews based on unsystematic and unmethodical techniques for collecting and compiling research data, enabling the presentation of reliable and credible scientific evidence in an objective manner" (Orłowska et al., 2017). In contrast, foreign literature describes the SLR as a review of scientific literature using a strictly defined set of methods to reduce 
systematic errors. In the process of realizing this task, the methodology is defined and described in detail and it is divided into 6 stages (Petticrew, Roberts, 2008).

According to this methodology, the SLR procedure involves the following stages: formulation of the research question, preparation of the report, searching the literature, data sorting and selection of items, data analysis, interpretation of results and conclusions, and publication and dissemination (Orłowska et al., 2017). The steps to create SLR are shown in Figure 1. The presented methodology has been used for analysis related to the concept of TA.

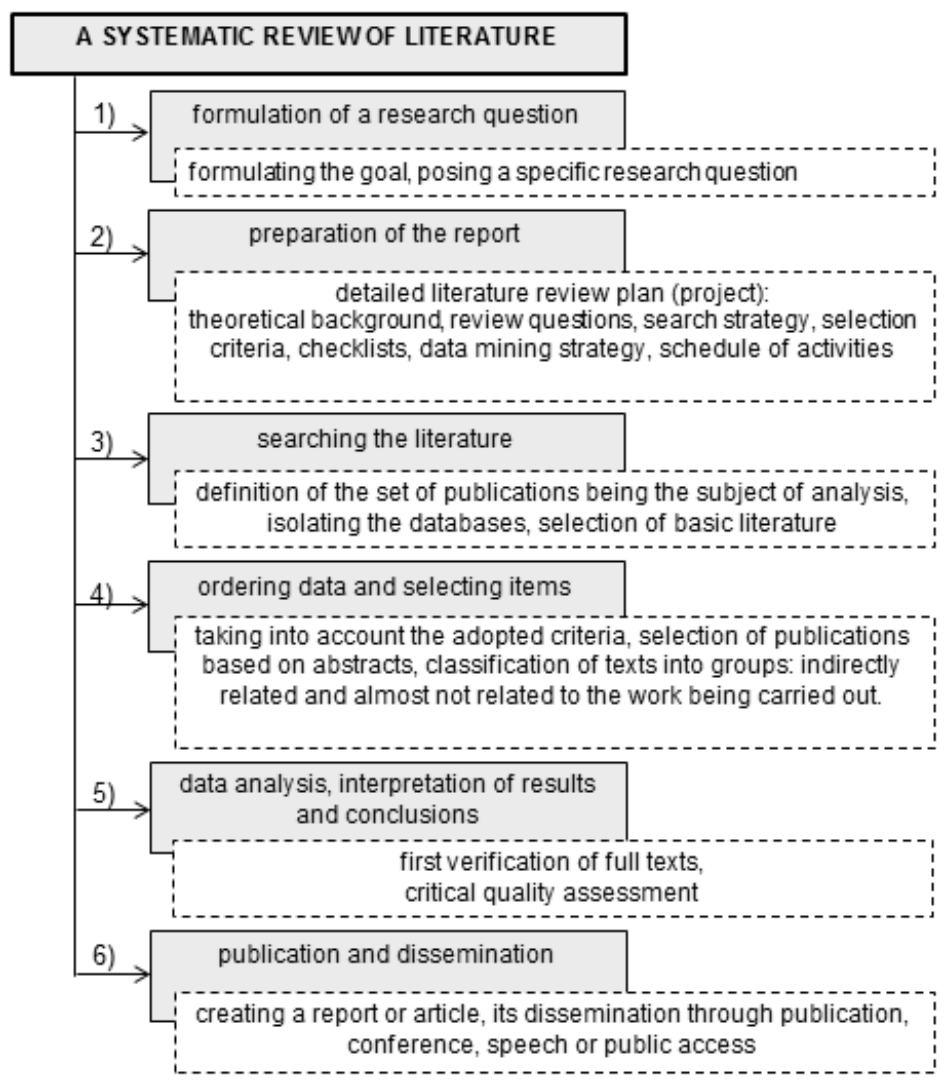

Fig.1. Stages of creating a systematic review of literature

Source: elaboration on its own basis (Orłowska et al., 2017).

\section{TECHNOLOGY ASSESSMENT IN SYSTEMATIC LITERATURE REVIEW}

The authors of the study attempted to use the SPL to recognize the current state of knowledge in the field of Technology Assessment. The identification of emerging trends in the country and in the world, will allow to determine the further direction of research in the verified area. The above-mentioned method of Systematic Review of Literature was used to identify research perspectives.

In the first stage, the following research questions were formulated:

- How is the term Technology Assessment defined in the literature?

- In which areas of science has the issue of Technology Assessment been used?

- How is the Technology Assessment area practically used?

- What are the research gaps in the field of Technology Assessment?

In the second stage, the criteria for literature search were formulated, subsidiary research questions were written, considered key words and topics were chosen and the contexts of the texts were planned. In particular, the attention was focused on the search for: unambiguous TA definitions, examples of practical TA application and determination of the research gap in the TA area. 
Next, two databases were selected: Google Scholar and BazTech, in which publications were sought in order to select the test sample.

Google Scholar is a tool that allows you to search for documents that are not included in other databases such as Scopus or WoS. In particular, this applies to conference materials, magazines or other publications published in a language other than English. Thus, it seems reasonable to claim that using the Google Scholar database gives greater opportunities to analyze the selected area (Matusek, 2015). BazTech, on the other hand, is a database of texts published in Polish technical journals in the field of technical and exact sciences. The database consists of libraries of 23 Polish colleges and universities. Currently, this database contains 419562 articles (web site BazTech). Initially, after entering the "Technology Assessment" term, the bases showed as many as 1170000 items. This number turned out to be too large for analysis. The reason for this is the widespread use of this keyword and the lack of a selective search criterion. After taking into account the selected criteria, the number of publications was limited to 1788 issued in 97 different journals.

Figure 2 presents a list of 13 selected magazines which contained the biggest number of articles containing the searched TA concept.

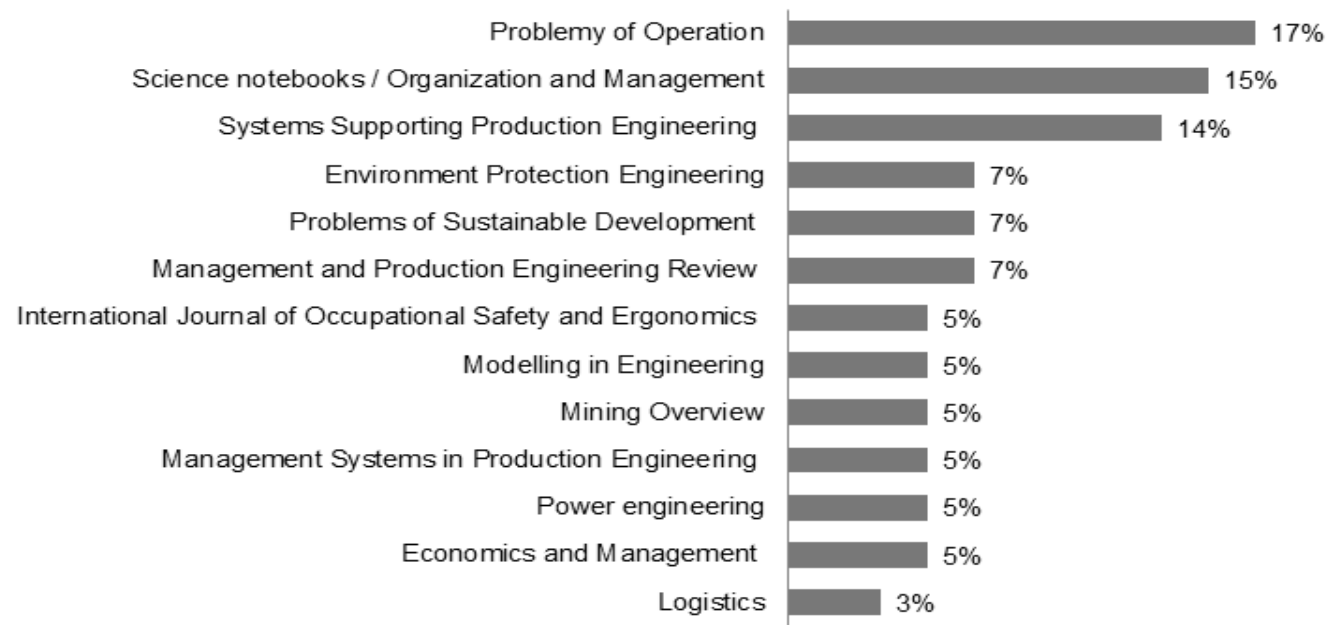

Fig. 2. List of magazines in which the concepts TA were most often found

Based on a review of the Google Books Ngram Viewer, a distribution of the number of publications containing the TA term was developed in years 1965-2015. The result is shown in Figure 3.

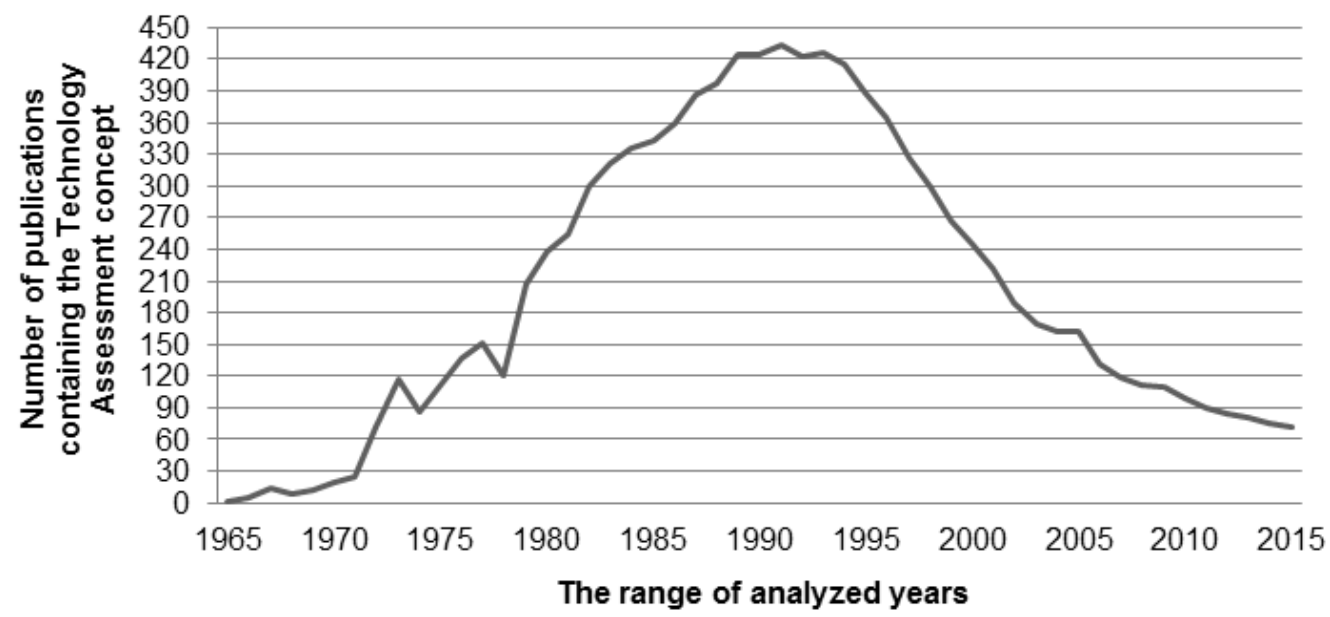

Fig. 3. Quantities of publications containing TA returns, in the years 1995 - 2018 Source: developed in-house on the basis of (Google Book, 2018). 
The next step was to organize the sources by analyzing the abstracts of the publication and classifying them into the appropriate group of texts: directly related, indirectly related or far connected with the subject of TA. The context of publication was also subject to selection, i.e. whether a particular text presented only the theory of the issue or also its practical application. In total, 777 articles were analyzed. The collected data has been compiled in a table, a fragment of which is presented in Table 1.

Table 1

Summary of systematic literature review in the field of technology assessment

\begin{tabular}{|c|c|c|c|c|c|c|c|}
\hline Title & Author & Journal & Year & Key words & $\begin{array}{c}\text { Area of the } \\
\text { issue }\end{array}$ & $\begin{array}{l}\text { Relation to } \\
\text { the topic }\end{array}$ & Application \\
\hline $\begin{array}{l}\text { Technology assessment - uwagi } \\
\text { wstępne o genezie i rozwoju }\end{array}$ & $\begin{array}{l}\text { Patrycja } \\
\text { Stylec }\end{array}$ & $\begin{array}{c}\text { Zeszyty Naukowe } \\
\text { Politechniki Sląskiej }\end{array}$ & 2015 & $\begin{array}{l}\text { technology assessment, ocena techniki, } \\
\text { filozofia techniki, technika, filozofia }\end{array}$ & $\begin{array}{c}\text { social } \\
\text { sciences }\end{array}$ & indirectly & theoretical \\
\hline \begin{tabular}{|c|} 
Rozwój innowacyjnych \\
technologii z perspektywy \\
partycypacyjnego modelu \\
technology assessment \\
\end{tabular} & $\begin{array}{l}\text { Janusz } \\
\text { Karwot }\end{array}$ & $\begin{array}{c}\text { Zeszyty Naukowe } \\
\text { Politechniki Sląskiej }\end{array}$ & 2018 & \begin{tabular}{|c|} 
profit, sharing management, model, \\
Assessment Technology, innovation, \\
decision, making process, knowledge, \\
social responsibility \\
\end{tabular} & $\begin{array}{l}\text { technical } \\
\text { studies }\end{array}$ & directly & practical \\
\hline $\begin{array}{l}\text { Assessment of the state of } \\
\text { technology and patent protection in } \\
\text { the process of technology transfer }\end{array}$ & $\begin{array}{c}\text { Kaczmarska } \\
\mathrm{B} \text {, et al. }\end{array}$ & \begin{tabular}{c|} 
Zarzadzanie \\
Przedsiębiorstwem
\end{tabular} & 2017 & $\begin{array}{l}\text { transfer of technology, assessment of the } \\
\text { state of technics, patent protection }\end{array}$ & $\begin{array}{l}\text { technical } \\
\text { studies }\end{array}$ & indirectly & $\begin{array}{l}\text { theoretical } \\
\text { / practical }\end{array}$ \\
\hline $\begin{array}{l}\text { Współczesne narzędzia oceny } \\
\text { technologii }\end{array}$ & $\begin{array}{l}\text { Małgorzata } \\
\text { Karczewska } \\
\text { et al. }\end{array}$ & $\begin{array}{c}\text { Innowacje } \\
\text { w zarzadzaniu } \\
\text { i inżynierii produkcji }\end{array}$ & 2011 & $\begin{array}{c}\text { technologia, ocena technologii, narzędzia } \\
\text { oceny technologii }\end{array}$ & $\begin{array}{l}\text { technical } \\
\text { studies }\end{array}$ & directly & $\begin{array}{l}\text { theoretical } \\
\text { / practical }\end{array}$ \\
\hline Prospektywna analiza technologii & $\begin{array}{c}\text { Katarzyna } \\
\text { Halicka }\end{array}$ & \begin{tabular}{c|} 
Innowacje w \\
zarzadzaniu i \\
inżynierii produkcji
\end{tabular} & 2015 & $\begin{array}{l}\text { analiza technologii, foresight } \\
\text { technologiczny, ocena technologii, } \\
\text { prognozowanie technologiczne }\end{array}$ & $\begin{array}{c}\text { technical } \\
\text { studies }\end{array}$ & directly & theoretical \\
\hline $\begin{array}{c}\text { Innovative classification of methods } \\
\text { of the Future-oriented Technology } \\
\text { Analysis }\end{array}$ & $\begin{array}{c}\text { Katarzyna } \\
\text { Halicka }\end{array}$ & $\begin{array}{c}\text { Innovative } \\
\text { classification of } \\
\text { methods of the } \\
\text { Future-oriented } \\
\text { Technology Analysis } \\
\end{array}$ & 2016 & $\begin{array}{c}\text { technology analysis, technology } \\
\text { foresight, TA, technology forecasting, } \\
\text { classification, Future-oriented, artificial } \\
\text { neural networks }\end{array}$ & $\begin{array}{l}\text { technical } \\
\text { studies }\end{array}$ & indirectly & theoretical \\
\hline $\begin{array}{l}\text { Technology assessment in } \\
\text { engineering practice }\end{array}$ & $\begin{array}{l}\text { Grunwald, } \\
\text { A. Et al.. }\end{array}$ & $\begin{array}{l}\text { Management } \\
\text { Systems in } \\
\text { Production } \\
\text { Engineering }\end{array}$ & 2013 & $\begin{array}{c}\text { technology assessment, energetic use of } \\
\text { biomass, process chain analysis }\end{array}$ & $\begin{array}{l}\text { technical } \\
\text { studies }\end{array}$ & indirectly & practical \\
\hline $\begin{array}{c}\text { Ewolucja wartościowania techniki w } \\
\text { obliczu różnych wyzwań - od } \\
\text { zwrotu normatywnego do } \\
\text { przemysłu } 4.0\end{array}$ & Kiepas, A. & $\begin{array}{l}\text { Zeszyty Naukowe } \\
\text { Politechniki Sląskiej }\end{array}$ & 2017 & Industry 4.0, Technology Assessment & $\begin{array}{l}\text { social } \\
\text { sciences }\end{array}$ & directly & theoretical \\
\hline $\begin{array}{c}\text { Uwagi na temat metod i narzędzi } \\
\text { oceny oddziaływań społecznych } \\
\text { innowacyjnych technologii i } \\
\text { produktow (Gechnology } \\
\text { Assessment') }\end{array}$ & $\begin{array}{c}\text { Kaźmierczak } \\
\mathrm{J} .\end{array}$ & $\begin{array}{c}\text { Systemy } \\
\text { Wspomagania w } \\
\text { Inżynierii Produkcji }\end{array}$ & 2013 & $\begin{array}{l}\text { Process of valuation, innovative } \\
\text { technologies, products, satisfying the } \\
\text { needs }\end{array}$ & $\begin{array}{l}\text { technical } \\
\text { studies }\end{array}$ & directly & theoretical \\
\hline
\end{tabular}

\section{ANALYSIS OF RESULTS}

Based on the obtained results, it can be stated that the term "Technology Assessment" is an interdisciplinary concept, and its application is used both in technical and social sciences. One of the meanings of TA is the technology assessment procedure, introduced by the Office of Technology Assessment which was established in the 1970s at the United States Congress. The procedure was to answer the question whether technologies appearing in the second half of the twentieth century should be considered as risky or dangerous. Currently, due to the very dynamic development of technology and its impact on society, the importance of TA increases very quickly (Stankiewicz, 2010)

According to the examined literature, the term TA is understood as an area that talks about technology assessment in terms of threats, development, innovation and the level of advancement. As Karwot writes, "TA is currently the basic element of the science and technology management system. This element has a decisive impact on shaping the European Union's scientific and technological policy. All decisions regarding the development of new solutions in technological sciences are taken by state institutions supported not only by a group of experts, but also with the participation of interested social groups, representatives of the business sphere, consumer organizations and non-governmental organizations and the public" (Krawot, 2018).

Other sources indicate that TA is a methodology of conduct in technology assessment containing a number of methods and tools. Karczewska, Materzok and Skonieczny write that TA is a complex methodology, containing a set of methods based on the following stages: problem determination, technology description, technology forecasting, social context description, social forecasting, impact identification, impact analysis, impact assessment, policy analysis, and informing about the results of the analysis (Karczewska et al., 2011). 
In addition, TA is understood as a tool that in itself evaluates technology. "Technology Assessment is an evaluation tool, valuating technology and setting directions for further development. It analyzes the impact of technology on society using user's feedback and the knowledge of international experts. Available literature sources describe TA as a systematic and comprehensive process of controlling and managing technology. The main objective of TA is to identify in advance the risk of the technologies introduced, which enables to determine and describe the effects of their implementation and to plan possible solutions to reduce this risk. TA is associated with the development of many alternative options of technological solutions used and the adaptation of innovative products to the needs and capabilities of selected user groups" (Kaźmierczak et al., 2013, 2015).

The presented fragment of literature research proves that the interpretation of the Technology Assessment issue is highly diversified, thus determining the development possibilities of this area both in science and industry. Current trends also point to research gaps in the interpretation of this issue. This creates the prospect of further research in this area. At the same time, there is the problem of scientific discipline in which this research area should be located. Production engineering seems to be natural in this respect, as it combines both technical and social as well as economic issues.

\section{CONCLUSION}

The dynamic development of technology and problems emerging with it, including the social ones, force activities to evaluate these new technologies. The area dealing with this issue is the broadly understood concept of Technology Assessment. It should be emphasized that this is a new concept that includes an area of research not yet defined. In order not to make a mistake within the meaning of this concept, a literature review was carried out, in the TA area, using the Systematic Review of Literature method. According to the authors, this method enables an objective examination of the existing literature on a given topic providing a lot of useful information. The analysis presented in the paper includes over 700 articles in which the concept of TA appeared. The collected research material presented a high degree of differentiation of the problem, indicating a fairly free interpretation of TA. However, it can be divided into three groups: a general area being an element of the science management system, a methodology of conduct containing specific procedures and a tool for assessing the technology. The obtained results indicate that TA is developing really dynamically, which is related to the development of technology. According to the authors, further research is necessary regarding both the users of new technologies as well as its producers and consumers.

\section{ACKNOWLEDGEMENTS}

This article is the result of research conducted at the Institute of Production Engineering, Faculty of Organization and Management, Silesian University of Technology, within the statutory work entitled "Development of intelligent production methods as well as work and life environments in the context of production engineering challenges" (symbol 13/030BK_18/0039).

\section{REFERENCES}

Barnicka, J. and Kabiesz, P. (2018). Znaczenie ergonomii w działalności przedsiębiorstw - przekrojowe studium literatury. Innowacje w zarządzaniu i inżynierii produkcji. Tom II. Oficyna Wydawnicza Polskiego Towarzystwa Zarządzania Produkcją Opole, pp. 397-408.

Brodny, J., Tutak, M. and Michalak, M. (2017). A Data Warehouse as an Indispensable Tool to Determine the Effectiveness of the Use of the Longwall Shearer. BDAS 2017, Beyond Databases, Architectures and Structures. Towards Efficient Solutions for Data Analysis and Knowledge Representation. pp.453-465. DOI: 10.1007/978-3-319-58274-0_36.

Czakon, W. (2011). Metodyka systematycznego przeglądu literatury. Przegląd Organizacji, vol 3, pp. 5761. 
Halicka, K. (2014). Zarządzanie technologiami z wykorzystaniem metody technology roadmapping. Zeszyty Naukowe Politechniki Śląskiej, nr 1919, seria Organizacja i Zarządzanie, Zeszyt 73, pp. 211-223.

Karatas, M., Ziya, and Rizaoglu, T. (2017). Technical characteristics of building isolation plates produced from natural materials such as: perlite, pumice micaschist and arenitized granite. Revista romana de materiale-romanian journal of materials 47.2, pp. 244-251.

Karczewska, M., Materzok, J. and Skonieczny, J. (2011). Współczesne narzędzia oceny technologii. Innowacje w zarządzaniu i inżynierii produkcji. Polskie Towarzystwo Zarządzania Produkcją, Opole, pp. 454-462.

Kaźmierczak, J. (2013). Uwagi na temat metod i narzędzi oceny oddziaływań społecznych innowacyjnych technologii i produktów „Technology Assessment”. Systems Supporting Production Engineering, 2 (4), pp. 47-54.

Kaźmierczak, J., Bartnicka, J., Janik, A., Loska, A., Pradela, A., Wieczorek, A. and Ziętkiewicz, A. (2015). Uwagi na temat wybranych problemów oceny oddziaływań społecznych innowacyjnych produktów i technologii („Technology Assessment”). Systemy Wspomagania w Inżynierii Produkcji, z. 2 (11), pp. 110-124.

Konsorcjum BazTech, (2018). [online] Available at: https://baztech.icm.edu.pl/ [Accessed 15 May 2018].

Krawot, J. (2018). Rozwój innowacyjnych technologii z perspektywy partycypacyjnego modelu technology assessment. Zeszyty Naukowe Politechniki Śląskiej, Organizacja i Zarzadzanie, z 113, pp. 141-155.

Matusek, M. (2015). Współtworzenie wartości z klientem-systematyczny przegląd literatury. Przegląd Organizacji, (10), pp. 5-11.

Orłowska, A., Mazur, Z. and Łaguna, M. (2017). Systematyczny przegląd literatury: Na czym polega i czym różni się od innych przeglądów? Ogrody Nauk i Sztuk, (7), pp. 350-363.

Palka, D., Brodny, J. and Stecuła, K. (2017). Modern means of production and the staff awareness of the technical in the plant of the mining industry. CBU International Conference Proceedings, Vol. 5. Central Bohemia University.

Petticrew, M. and Roberts H. (2008). Systematic reviews-do they 'work' in informing decision-making around health inequalities? Health eco-nomics, policy, and law, 3, pp. 197-211. ISSN 1744-1331 DOI:10.1017/S1744133108004453

Stankiewicz, P. (2010). Teoria i praktyka oceny technologii. Infos. Zagadnienia społeczno-gospodarcze.

Stecuła, K., Brodny, J. and Tutak, M. (2017b). Informatics platform as a tool supporting research regarding the effectiveness of the mining machines' work. In: CBU International Conference Proceedings 2017: Innovations in Science and Education, Vol. 5, Prague 2017, p. 1215-1219. DOI 10.12955/cbup.v5.1099.

Stecuła, K., Brodny, J. and Tutak, M. (2018). Use of intelligent informatics module for registration and assessment of causes of breaks in selected mining machines. In: Intelligent Systems in Production Engineering and Maintenance ISPEM 2017, Advances in Intelligent Systems and Computing 637, pp.74-84.DOI 10.1007/978-3-319-64465-3_8.

Stecuła, K., Tutak, M. and Brodny, J. (2017a). Application of chosen elements from japanese production and maintenance management philosophies in polish coal mines. In: SGEM 2017. Vol. 17, issue 13. Bulgaria 2017. pp. 93-100. DOI: doi.org/10.5593/sgem2017/13.

Tutak, M. (2017a). Analysis of varying levels of methane emissions from coal mines in Poland. In: SGEM2017 Vienna GREEN Conference Proceedings, Vol. 17, Issue 43, 301-308 pp; DOI: 10.5593/sgem2017H/43/S19.038.

Tutak, M. (2017b). Assessment of hydrodynamics of gas flow through the porous rock structures. In: SGEM2017 Vienna GREEN Conference Proceedings, Vol. 17, Issue 15, 53-60 pp; DOI: 10.5593/sgem2017H/15/S06.007.

Tutak, M. and Brodny, J. (2017b). Determination of Particular Endogenous Fires Hazard Zones in Goaf with Caving of Longwall. IOP Conf. Series: Earth and Environmental Science 95, 042026 doi:10.1088/1755-1315/95/4/042026.

Tutak, M., Brodny, J. (2017a). Impact of type of the roof rocks on location and range of endogenous fires particular hazard zone by in goaf with caving. E3S Web Conferences Volume 29, 2018, pp. E3S Web of Conferences Copyright / Published by: EDP Sciences; https://doi.org/10.1051/e3sconf/20182900005. 